\title{
Influence of Recruitment Practice on Lecturers' Performance in Kenyan Public Universities
}

\author{
Wyckliffe Otieno Robby ${ }^{1 *}$ Dr. Fredrick Aila ${ }^{2}$ Prof. Isaac Ochieng ${ }^{3}$ \\ 1. Department of Business Administration, Maseno University, P.O. Box 333-40105, Maseno, Kenya \\ 2. Department of Business Administration, Maseno University, P.O. Box 333-40105, Maseno, Kenya \\ 3. Department of Commerce, Laikipia University P.O. Box 1100-20300, Nyahururu - Kenya \\ *Email of the Corresponding Author: robirowa@gmail.com
}

\begin{abstract}
Public universities are key players in pursuit of Kenya Vision 2030's mandate of providing globally competitive quality education, training and research to the citizenry. However, higher education stakeholders including the World Bank, Kenya's Commission for University Education, employers and scholars have expressed misgivings regarding quality and relevance of these institution's academic programmes. Declining quality is attributed to increased workload, reduced rigour in recruitment and promotion criteria, failure to attract and retain quality faculty, and alleged lecturers' incompetence. Empirical studies relating recruitment practice (RP) to employee performance (EP) ignore both descriptors of RP like: examining vacancy; locating, making contact and attracting candidates as well as lecturers' performance measures such as: quality of teaching and learning; research and publication; administration and other responsibilities; and community engagement and other contributions. The purpose of this study was to establish influence of recruitment on lecturers' performance in Kenyan public universities. It was guided by Simon's decision making theory and reinforced by Barney's resource based view; Adam Smith's human capital theory; and Herzberg's two-factor theory. It adopted descriptive cross-sectional survey research design with a target population of 1,653 lecturers in 14 chartered public universities established between 2009 and 2019. Multi-stage purposeful sampling technique was used to finally take a census of 158 academic heads of departments (lecturers) from 13 out of the 14 universities, having used 20 in piloting. Public universities were targeted since they account for $72 \%$ of the teaching total university teaching faculty. Semistructured questionnaires were used to collect primary data while secondary data were obtained from relevant secondary sources. Cronbach's alpha coefficient was used to examine the internal consistency at $0.796(\mathrm{SD}=0.067)$. Whereas content validity was ascertained by reviewing literature within the domain of study concepts and corroborated by a panel of experts, construct validity was measured using Pearson's r. Data were analyzed using Pearson's $r$ and regression analysis. The correlation between recruitment practice and lecturers' performance was established to be positive and significant $(r=.324, p=.000)$. Recruitment practice accounted for $11.6 \%$ (Adjusted $\left.R^{2}=.116\right)$ of the variation in the lecturers' performance in Kenyan public universities. The findings are useful to the management of public universities and HRM practitioners in formulating and implementing recruitment strategies; researchers as well as organizational behaviourists and theorists.
\end{abstract}

Keywords: Recruitment, lecturers' performance, candidates' assessment, choice and employment.

DOI: $10.7176 / \mathrm{EJBM} / 13-20-16$

Publication date:October $31^{\text {st }} 2021$

\section{Introduction}

Higher education seeks to improve the social life of a nation (Teir and Zhang, 2016) given its importance in the promotion of social equity and economic security (Hudson, 2016; Malee-Baset, 2015). Higher education facilitates economic transformation by supporting lower levels of education, preparing professionals and skilled labour, as well as serving as an incubator for research (World Bank, 2017). It is against this backdrop that Kenya Vision 2030 was conceived to among others provide globally competitive quality education, training and research to her citizens for development and enhanced individual wellbeing (Republic of Kenya, 2007). Higher education comprises a range of higher learning institutions including the university (Alemu, 2018). The role of universities in preparing human resources for sustainable development of nations is monumental (Kara, Tanui and Kalai, 2020). Ironically, the quality and relevance of higher education, value for money and resource allocation in the sector have raised a lot of concerns among stakeholders (World Bank, 2017; Johnson, Kirimi and Gathara, 2018; Ball, 2012; Adeyemi, 2017).

In Africa, the quality of higher education has largely been observed to be poor hence necessitating urgent attention (Afolabi and Idowu, 2019). Some African countries such as Ethiopia, Madagascar and Nigeria acknowledge the poor quality of higher education in the respective countries and appreciate the need to improve towards 
international standards (Materu, 2007). Generally, enrolment in Sub-Saharan African countries' higher education institutions has outgrown financing capacities thus insufficient resources, and the attendant decline in the quality of instruction and inability to innovate (World Bank, 2010). The declining quality is evident in falling scores in examinations, reduced rigour in recruitment and promotion criteria, diminished research and complaints by employers regarding the calibre of university graduates (World Bank, 1996).

Kenya is facing a major challenge in ensuring quality higher education (McCowan, 2018). Whereas university education therein endeavours to advance knowledge through quality teaching, scholarly research and scientific investigation (Republic of Kenya, 2012; Commission for University Education, 2016), stakeholders question the quality and relevance of programmes offered therein (Yego 2016; Kaburu, 2014; Martin and Anthony, 2007; Ajayi, 1996). Oanda and Jowi (2012) gauged quality in terms of calibre and adequacy of academic staff, learning and teaching facilities, contact hours, entry behaviour of learners and governance structures - variables that they observed to be lacking in the universities. A Delphi survey (2010) termed quality a misnomer in Kenyan university education as universities had become production lines that "bite more than they can chew" (Kimathi and Embeywa, 2014). Odhiambo (2018) expresses concerns about the ability of Kenya's universities to produce graduates capable of driving the country forward. Many other stakeholders share similar concerns (Kala, Tanui and Kalai, 2020; Johnson, Kirimi and Gathara, 2018; Wanzala, 2015; British Council, 2014; Ponge, 2013). A study by University Council of East Africa (2014) as cited in McCowan (2018) revealed that 49\% of graduates were inadequately prepared for work in their respective areas of specialization.

Jones and Walters (1994) attribute the success of educational systems to the quality of their human resources, and prioritizing human resource management in their administration. Obwogi (2019) posits that human resource management practices including recruitment and selection can potentially affect quality. Human resource management policies, for instance, provide a blue print for enhancing educational delivery in countries (Essaw and Issahaku, 2013). According to Hossain and Rahman (2019), the most valuable human resources in higher educational institutions are lecturers.

There is consensus that quality of education, training and learning is influenced by lecturers among other factors (Kala, Tanui and Kalai, 2020; Wanzala, 2013; UNICEF, 2000). Students' academic performance has overtime been linked to the effectiveness of the teacher in terms of teaching and learning (Ajao, 2001). Deepa and Manisha (2014) observe that effective learning is a function of effective teaching by effective lecturers. It is, therefore, probable that the declining performance in universities is partly domiciled in the calibre of lecturers they employ thus the interest in their performance. Ngolovoi (2006) attributes the decline to increased workload and alleged incompetence of lecturers. Mwiria and Nyukuri (1994) fault double intake of students for having relaxed the criteria for recruitment of new staff as well as the promotion of the existing ones. Wanzala (2013) explains that the recruitment and appointment procedure for staff in institutions of higher learning are, on many occasions, not competitive or transparent leading to the employment of inefficient staff. Collectively, these reflect the challenges that public universities face with respect to recruitment practices and the attendant performance.

This study sought to examine the influence of recruitment practice on lecturers' performance in Kenyan public universities. The fact that public universities account for $72 \%$ of the total university teaching staff (Commission for University Education, 2016) explains the interest. Specifically, chartered public universities established between 2009 and 2019 were targeted because of the staffing challenges they are faced with (Ikama, 2010) and pressure exerted on them to provide employment (Mukhwana, Oure, Too and Some, 2016). The study was anchored on decision-making theory (Simon, 1945; Mintzberg, 1973; Iyayi, 2002) and supported by the resource based view (Barney, 1991); human capital theory (Terence, 1976) and the two-factor theory (Herzberg, Mauster and Snyderman, 1957).

\section{Literature Review}

\subsection{Review of Theoretical Literature}

\subsubsection{Theoretical Foundation}

The decision making theory, which was the overarching theory, was reinforced by Barney's resource based view; Adam Smith's human capital theory and Herzberg's two-factor theory. The decision-making theory emanates from the studies by Simon (1945), Mintzberg (1973) and Iyayi (2002) on decision making in organizations. It is premised on the significant role of decision-making in organizational success (Gberevie, 2006). Decision-making theorists view decisions as the selection of a proposed course of action (Butler, 1992; Iyayi, 2002). The decisions guide several human resource management practices including recruitment practice, which theoretically relates to employee performance. With regards to recruitment practice, managers may need to decide on the recruitment criteria, sources of candidates and choice of recruitment media, among others. 
The resource based view was propounded by Barney (1991). It perceives human resources as important factors in attaining competitive advantage, and realizing organizational goals and targets (Barney, 2001). Strategic capability of an organization, according to the theory, is premised in its resource capability in form of her employees (Armstrong, 2009). HRM adds value through the strategic development of the rare, hard to imitate and hard to substitute human resources (Barney, 1991). In respect of this study, the theory draws its relevance from its focus on the quality of human resources available to an organization and their ability to adapt more quickly relative to their competitors (Katua and Gachunga, 2014) hence optimum performance. Barney (2001) encourages firms to constantly evaluate their workforce to ensure that they have the right people with the right skills in the right places to assure sustained competitive advantage. In the event of any shortfalls, firms are advised to employ appropriate recruitment and selection criteria (Ekwaoba, Ikeije and Ufoma, 2015) or, in the alternative, initiate training and development programmes for the existing employees so as to enhance their knowledge, skills and abilities.

The stance of human capital theory that was propounded by Adam Smith (Terence, 1976) is that people are fixed capitals, just like machines owing to the fact that their skills and abilities have costs and yield profits (Teixeira, 2002). It is premised on the assertion that people and their collective skills, abilities and experience, coupled with their ability to deploy these in the interest of the firm contribute to its competitive advantage and success (Armstrong, 2006). Boxall (1996) views this situation as one that confers "human capital advantage". According to the theory, sustainable competitive advantage is attained when the firm has a human resource pool that cannot be imitated or substituted by its rivals. Firms which recruit and retain exceptional individuals can create competitive advantage for themselves (Boxall, 1998) in addition to generally enhancing their performance.

\subsubsection{Recruitment}

According to Nzuve (2010), recruitment is a fundamental function in the management of human resources in large organizations. It is the first part of the process of filling a vacancy which includes: the examination of a vacancy, locating candidates, making contact and attracting applications from suitable candidates (Graham and Bennett, 1998). It is aimed at finding and engaging the people needed by an organization (Armstrong, 2009). DeCenzo and Robbins (1998) define it as the discovering of potential candidates for actual or anticipated organizational vacancies. It should attract a large number of qualified candidates to choose from, and provide information that enables unqualified applicants to self-select themselves out of the job candidacy. The process of recruitment is only complete in as far as it attracts qualified job applicants (Nzuve, 2010).

Recruitment can be internal or external. Internal recruitment implies looking inside the organization for existing qualified employees who might be promoted to higher positions while external recruitment refers to looking outside the organization for prospective employees (Graham and Bennett, 1998; Armstrong, 2009; Nzuve, 2010; DeCenzo and Robbins, 1998; DeNisi and Griffins, 1998). For recruitment to achieve its objective, DeCenzo and Robbins (1998) suggest that recruiting sources should reflect the type of position to be filled. While both internal and external recruitment have a range of merits and demerits (Armstrong, 2006; Armstrong, 2009; Dessler, 1998; DeNisi and Griffin, 1998; DeCenzo and Robbins, 1998; Beardwell and Claydon, 2007; Graham and Bennett, 1998; Torrington et al. 2008; Ivancevich, 2010), Armstrong (2009) opines that priority should be given to the internal candidates. As such, external recruitment is only recommended when an organization is unable to get a suitable candidate from within. DeNisi and Griffin (1998) elucidate three methods of internal recruitment: job posting, supervisor recommendations and union halls. Dessler (2008) expands the list by adding personnel records and skill banks. The most common methods of external recruitment are: online or e- recruitment; advertising; employment agencies; referrals, recommendations and walk-ins; educational institutions; temporary help services and professional organizations (Armstrong, 2009; Dessler, 1998; DeNisi and Griffin, 1998; DeCenzo and Robbins, 1998; Beardwell and Claydon, 2007; Graham and Bennett, 1998; Torrington et al. 2008). They note that each of the methods has its merits and demerits.

\subsubsection{Lecturers' Performance}

Performance is a multi-dimensional construct (Dugguh \& Ayaga, 2014). Performance in organizational context is broad and has been a subject of study among social scientists from a wide range of disciplines, and can be used synonymously with productivity, efficiency, effectiveness and, more recently, competitiveness (Cooke, 2001). Performance incorporates behaviour and results (Brumbach, 1998; Dugguh \& Ayaga, 2014). Behaviour emanates from performer and transforms performance from abstraction to action. Employee performance implies the jobrelated activities expected of employees and how they are executed (Dugguh and Ayaga, 2014). Lecturers are employees of universities charged with transforming developing and disseminating knowledge through education, research and community service. Consequently, their performance is primary to the success of a university. Lecturers' performance can, therefore, be defined as the job related behaviours and results expected of lecturers 
(Brumbach, 1998; Dugguh and Ayaga, 2014).

There are divergent indicators of lecturers' performance. A measure is a specific quantitative or qualitative representation of capacity, process or outcome deemed relevant to the assessment of performance. Lecturers' performance can be measured by subject knowledge, testing or assessment procedure, student-teacher relations, organizational skills, communication skills, subject relevance and utility of assignments (Molefe, 2010). SánchezBarrioluengo (2013) in World Bank (2017) explains that the higher education community generally identifies three distinct but interrelated missions: teaching and learning, research and community engagement against which the performance of lecturers could be measured.

Abba and Mugizi (2018) summarize the performance of academic staff as being indicated by: teaching, research and publication, innovation and community service while Commission for University Education (2014a and 2014b) wrap lecturers' performance around four thematic areas: quality of teaching and learning; research and publication; administration and responsibilities and community engagement and other contributions. As a policy, the commission embedded the appointment and promotion of academic staff in public universities in the four areas through a document entitled "Harmonized Criteria and Guidelines for Appointment and Promotion of Academic Staff in Universities in Kenya". While the document was challenged in a court of law by University Academic Staff Union, the contention was not on the performance areas. Universities have, therefore, largely retained the performance areas with some variations on weighting. This study therefore, adapted the Commission for University Education's indicators, and blended them with relevant dimensions of measures proposed by other researchers in Molefe (2010).

Quality of teaching and learning is measured by the following: student evaluation of the instructor and course; the lecturer's notes; ability to advise and mentor students; training in higher education teaching and post graduate supervision (Commission for University Education of Kenya, 2014a and 2014b). Whereas student evaluation may court controversy, Balam and Shannon (2010); and Bedggood and Donovan (2012) submit that there is sufficient literature to conclude that they are generally consistent and valid (Arnold, 2008 and Liu, 2012). Related to these is a lecturer's knowledge-base in the subject as proposed by Analoui (2007) who views it as being fundamental to the creation and enhancement of the student's opportunity to learn well. Knowledge base encompasses declarative knowledge of facts and concepts, the procedural knowledge of what to do, and the motivation includes the effort and persistence to excel (Aguinis, 2009). Ganyaupfu (2013) adds the teaching skills of a lecturer to this list. He explains that a lecturer's teaching skills is based on their ability to comprehend and transform concepts to be imparted to learners. Shulman (1992) views comprehension as a key element of lecturers' competence. Sinclear and Johnson (2000) assert that thorough knowledge of the subject material is essential to accurate instruction and clear communication and content to students. Arreola (2000) opines that the quality of teaching and learning should also include expertise in the content area.

In addition to content knowledge, ability to organize, integrate, adjust and adapt this content in ways that make it accessible and thought provoking to the learner are the other parameters of quality of teaching and learning (Gill and Johnson, 1997; White, 2008). Testing or assessment procedure which entails designing, developing and implementing tools and procedures for assessing students' learning outcomes and is part of the instructional design (Molefe, 2010) also contributes to the quality of teaching. Arreola (2000) identifies requisite skills under this dimension as: designing tests; preparing the learning objectives; developing syllabi; preparing handouts and other supporting materials; properly using media and other forms of instructional technology and organizing lectures and presentations for maximal instruction. Hill, Lomus and MacGregor (2003) add feedback to students during the sessions and assignments to this list.

Molefe (2010) further points out the importance of student-teacher relations in teaching and learning. He relates it to the creation and maintenance of student-centred environment that maintains and sustains learning and development. According to him, it is a dimension that is integral to high learner-performance. Arreola (2000) asserts that a teacher who can develop relationships that foster and encourage students will enhance learning. Encouragement of active participation in the classroom creates a supportive environment where questions and class discussions are promoted, which imbues the lecturer with enthusiasm for the subject and facilitates opportunities for generating regular informal feedback on students as well as deeper understanding of the subject matter (Sinclair and Johnson, 2000).

Sinclair and Johnson (2000) opine that organizing skills is another dimension that influences overall student experiences, as well as the quality of teaching. Included herein is also the bureaucratic skills utilised for operating and managing a course including, but not limited to, timely grading of examinations, maintaining published office hours, arranging for and coordinating guest lecturers and generally making arrangements for facilities and 
resources required in the teaching of the course. In support of this stance is Arreola (2000) who asserts that excellent teachers do their work in a well-prepared and well-organized manner by arranging their activities in a way that allows them time to engage in corporate citizenship and community outreach. It is worth noting that corporate citizenship and community outreach are other measures of lecturer performance according to the Commission for University Education (2014a and 2014b).

Molefe (2010) further identifies communication as an important aspect of structural delivery skills that enhances teaching and learning. Clarity in exposition, demonstrated enthusiasm, ability to motivate, ability to capture and hold the interest and attention of learners and create an overall learning environment appropriate to the content being taught are all included in communications skill dimension (Arreola, 2000). According to Hill et al., 2003 and White, 2008, subject relevance is another factor that concerns learning and teaching quality. It relates to the appropriateness of the content provided during the lesson and the way in which it is presented to the learners. They suggest that it should entail accuracy of the facts encapsulated in the course content. Relevant assessment instruments used in the course should add to the design of architecture within the frame of reference of the course materials and the real world associated with the subject. Questions should be set at the appropriate level and graded according to the learning outcomes of the module. The text books and reference materials recommended by the lecturers, as well as the appropriate use of methods and techniques used in the subject are also of vital importance. The course being offered should also be of value to the workplace.

Towards enhancing the quality of teaching and learning, White (2008) opines that the assignments given to students should be meaningful and ones that enhance their learning and developmental needs. The assignments should be within the frame of reference of the course materials and the real world associated with the subject and socioeconomic life within which a student lives. To further enhance utility, Layman, Williams and Staten (2007) suggest that the assignment should reflect its learning objectives and make it interesting and challenging to the student.

Research and publication as an indicator of lecturers' performance generally implies the ability to advance scholarship and generate research as advanced by Gill and Johnson (1997) and White (2008). Implicit in the generation of research is the advancement of knowledge through discovery, integration, dissemination and application of knowledge. Commission for University Education (2014b) suggests that it entails: publication of scholarly books and chapters in books; refereed journals; refereed learning modules; reviewed conference papers; non-reviewed conference papers; short communication in a refereed / scholarly journals; book reviews published in refereed journals; editorship of books and conference proceedings; scholarly presentations at conferences, workshops or seminars; refereed exhibitions and performances; consultancy and project reports; and patented invention and innovation. While these measures advance a quantitative component (i.e. numbers of), Harvey et al. (2010); Long et al. (2009) and Stack (2003) in Cadez, Dimovski and Groff (2017) suggest that the quality aspect be interrogated via the impact and quantity of papers published in an exclusive set of high quality journals or by the number of citations.

Administration and responsibilities as a measure of lecturers' performance encapsulates recognized university administrative positions and any other responsibilities that may be assigned to a lecturer. Community engagement and other contributions, on the other hand, is rated by the ability of a lecturer to attract research and development funding; engagement in community service and outreach, professional affiliations and portfolios, recognition, awards and honours amongst others as determined by individual universities (Commission for University Education, 2014b).

\subsection{Review of Empirical Literature}

\subsubsection{Recruitment Practice and Lecturers'Performance}

Reviewed studies relate recruitment directly or indirectly to either employee or organizational performance. Saifalislam, Osman and AlQudah (2014) not only relate recruitment to organizational performance, which is a function of many other variables, but fail to specify the indicators of recruitment. Suwarto and Subyantoro (2019); Rahmany (2018); Murage, Sang and Ngure (2018); Oaya, Ogbu and Remilekun (2017); Suntanto and Kurniawan (2016); Ombui Mukulu and Waititu (2014) and Mokaya, Mukhweso and Njuguna (2013) all relate recruitment to employee performance variously. Suwarto and Subyantoro (2019) considered basis for hiring, sources of employees and recruitment method as the indicators of recruitment; Rahmany (2018) focused on factors that affect recruitment process which he identified as nepotism, politicization, corruption, patronage and instability. Murage, Sang and Ngure (2018) whose interest was on ethical issues that affect recruitment basically identified unethical practices that need not characterize recruitment such as sexual harassment, bribery, nepotism and discrimination; Oaya, Ogbu and Remilekun (2017) focused on recruitment strategy that they operationalized to comprise only three methods of recruitment: employee referrals, employment agencies and host community member recruitment; 
Mokaya, Mukhweso and Njuguna (2013) considered recruitment sources, recruitment policies and recruitment message as the descriptors of recruitment practice. Both Suntanto and Kurniawan (2016) and Ombui, Mukulu and Waititu (2014) are not specific on the elements of recruitment they studied despite its varied components. Therefore, none of them studied the facets of recruitment such as examining vacancy; locating, making contact and attracting candidates (Graham and Bennett, 1998).

Revealing a positive significant relationship between the various facets of recruitment and employee performance are Rahmany (2018); Murage, Sang and Ngure (2018); and Suntanto and Kurniawan (2016). Ombui Mukulu and Waititu (2014) discovered a positive moderate relationship while Mokaya, Mukhweso and Njuguna (2013) found a positive significant, but weaker relationship. Oaya, Ogbu and Remilekun (2017) discovered a significant positive relationship between employee referral recruitment and employment agency recruitment (facets of recruitment strategy), and employee commitment and productivity (facets of employee performance) respectively. However, host community member recruitment revealed no significant relationship with employee efficiency (facet of employee performance). Suwarto and Subyantoro, (2019) established that recruitment had no effect on employee performance. The results were, therefore, mixed.

None of the specific studies that investigated the relationship between recruitment practice and employee performance (Suwarto and Subyantoro, 2019; Rahmany, 2018; Murage, Sang and Ngure, 2018; Oaya, Ogbu and Remilekun, 2017; Suntanto and Kurniawan, 2016; Ombui, Mukulu and Waititu, 2014; Sifalislam, Osman and AlQuda, 2014; Mikaya, Mukhweso and Njuguna, 2013) involved the entire facets of recruitment such as examining vacancy: locating, making contact and attracting candidates (Graham and Bennett, 1998).

\section{Research Methodology}

4.1 Research Design

Research design refers to the arrangements of the conditions for collection and analysis of data in a manner that aims to combine relevance to the research purpose with economy in procedure (Kothari 2004). The study adopted descriptive cross-sectional survey research design in data collection and analysis. A survey research design is scientific method of inquiry in which the researcher selects a sample of respondents and administers a standardized research instrument on them (Rubin and Babbie, 2001) define. Descriptive research studies describe the characteristics of a particular individual, or of a group and facilitate predictions, with narration of facts and characteristics concerning individuals, groups or situations (Kothari and Garg, 2014). Creswell (2009) observes that surveys as forms of quantitative strategies can provide quantitative or numeric description of trends, attitudes, or opinions of a population by studying a sample of that population. The study used academic heads of departments as the unit of analysis. Cross-sectional survey was preferred because it facilitated the collection of data from various cases at the same time hence a variety of views over the same issue captured within a short time. The correlational approach assisted in establishing whether there existed a significant association between the independent and the dependent variables (Mugenda, 2008; Kothari and Garg, 2014). Creswell (2009) opines that questionnaires can be used to collect data in cross-sectional study.

\subsection{Study Area}

The study focused on 14 chartered public universities that were established between 2009 and 2019, but spread across the Republic of Kenya. Kenya lies between Latitude: $0^{\circ} 10^{\prime} 36.73$ " N and Longitude: $37^{\circ} 54^{\prime} 29.98^{\prime \prime}$ E, and on the equator with the Indian Ocean to the South-East, Tanzania to the South, Uganda to the West, South Sudan to the North-West, Ethiopia to the North and Somalia to the North-East. The country was targeted due to the misgivings that Higher Education stakeholders have expressed regarding the quality of education in her universities (Mwiria and Nyukuri, 1994; Ngolovoi, 2006; Wangenge-Ouma, 2007; Gudo, Olel and Oanda (2011); Kaburu (2014) and Ayiro (2015).

\subsection{Target Population}

Target population is the population of interest in a given study. It is the theoretical population (Umar, 2018). According to Bartlett et al. (2001), target population is the group of individuals or participants with specific attributes of interest and relevance. It is, therefore, the part of general population that is left after refining and eliminating all individuals whose involvement in the study would breach the research goal, assumptions or context. The target population of the study comprised all the 1,653 lecturers in the fourteen (14) chartered public universities established between 2009 and 2019. Any lecturer outside this specification was, therefore, excluded.

Accessible population is arrived at after eliminating all individuals who may not participate or who cannot be accessed in the course of the study (Bartlett et al., 2001). It constitutes the final group from which data is collected in whole or as a sample. It, therefore, represents the sampling frame. Accordingly, the accessible population of the 
current study comprised all the 178 AHoDs/ Deans/Directors of schools or faculties in the 14 chartered Kenyan public universities established between 2009 and 2019.

\subsection{Sample Design and Size}

Sample design is a definite plan for obtaining a sample from a given population. It refers to the technique or procedure that the researcher adopts in selecting items for a sample. It may lay down the number of items to be included in the sample (Kothari, 2004). The study adopted multistage purposeful sampling technique (Table 1) in which the study sample was selected in two stages purposively (Omona, 2013; Onwuegbizie and Leech, 2007). In the first stage, the study purposively focused on 1,653 lecturers in the 14 chartered public universities established between 2009 and 2019 (its target population), from the general / entire population of 8,737 lecturers in the 31 chartered public universities in Kenya as at $20^{\text {th }}$ October, 2019. The universities 14 universities were selected on the basis of the staffing challenges they are faced with (Ikama, 2010: Kagondu and Marwa, 2017) and the pressure exerted on them to employ (Mukhwana et al., 2016).

Judgment sampling was then purposively employed, in the second stage, to take a census of 178 academic heads of departments (AHoDs) in the 14 chartered public universities since they were considered information rich. The AHoDs normally participate in making recruitment decisions. They are also the immediate supervisors of the lecturers in their respective departments hence better placed to monitor and assess their performance. Their choice was further qualified by the fact that they are representative of all the categories of lecturers considering that they are drawn from disparate ages, gender, academic positions or ranks and qualifications across the universities apart from being lecturers themselves. The deans and directors of schools and institutes that were not established as departments under existing schools or faculties were considered the AHoDs. The census of 158 was adopted due to the limited number that remained after conducting a pilot study on 20 AHoDs from Jaramogi Oginga Odinga University of Science and Technology (JOOUST). JOOUST was selected using simple random sampling technique. Monette, Sullivan and Dejong (2002) suggest that a sample of 20 respondents is sufficient for pilot testing in a survey.

Table 1: Multistage Purposeful Sampling Procedure

\begin{tabular}{|c|c|c|c|c|}
\hline Stage & No. of Universities & $\begin{array}{l}\text { Total No. of } \\
\text { Lecturers }\end{array}$ & Population Type & Sampling Technique \\
\hline & $\begin{array}{l}31 \text { Chartered Kenyan Public } \\
\text { Universities. }\end{array}$ & 8,737 & $\begin{array}{l}\text { General/Study } \\
\text { Population }\end{array}$ & $\begin{array}{l}\text { Entire population of } \\
\text { lectures }\end{array}$ \\
\hline 1. & $\begin{array}{l}14 \text { Chartered Kenyan Public } \\
\text { Universities established between } \\
2009 \text { and } 2019 .\end{array}$ & 1,653 & Target Population & Purposive Sampling \\
\hline 2. & $\begin{array}{l}14 \text { Chartered Kenyan Public } \\
\text { Universities established between } \\
2009 \text { and } 2019 .\end{array}$ & $\begin{array}{l}178 \\
\text { (A census of AHoDs/ } \\
\text { Deans/ Directors) }\end{array}$ & Accessible Population & $\begin{array}{l}\text { Purposive and } \\
\text { Judgement Sampling }\end{array}$ \\
\hline
\end{tabular}

Source: Preliminary Survey, 2019

\subsection{Data Collection Methods}

\subsubsection{Data Type and Sources}

Both primary and secondary data were collected. Primary data was drawn from the respective AHoDs using semistructured questionnaires while secondary data extracted from journal articles, human resource records, audit reports, relevant books and institutional websites. Cooper and Schindler (2008) applaud primary data for their proximity to the truth and control over error.

\subsubsection{Data Collection Procedures}

Prior to the administration of the data collection instrument, the researcher first obtained authorization to collect data from the School of Graduate Studies, Maseno University; Maseno University Ethical Review Committee; and research permit from National Commission for Science, Technology and Innovation. Permission to collect data was then sought and obtained from the administration of the respective universities that comprised the study. This was followed by an informal familiarization visit to the targeted universities to create rapport and locate the relevant offices, and respondents. It is at this point that the researcher obtained tentative dates and time for the 
administration of the questionnaires at the convenience of the respondents.

The research questionnaire had hitherto been given to a panel of seven experts, in consultation with the researcher's supervisors, for review. Having incorporated their suggestions which included summarizing the items that were considered wordy, use of common words, reconstruction of poorly constructed item and blending of negative and positive statements in the questionnaire items, it was then piloted on twenty (20) AHoDs drawn from Jaramogi Oginga Odinga University of Science and Technology and their suggestions incorporated too. Monette, Sullivan and Dejong (2002) suggest that a sample of 20 respondents is sufficient for pilot testing in a survey.

Accordingly, the questionnaire items were adjusted for reliability and validity based on the pilot results and the AHoDs suggestions. All the proposals that were advanced by the AHoDs were considered. They included shortening of the questionnaire by omitting redundant and overlapping items, simplifying items, summarizing items that appeared verbose; reconstructing poorly constructed items and elimination of ambiguities. Pilot study, according to Orodho (2005), helps determine both the validity and reliability of the research instruments. The AHoDs used in piloting were ultimately excluded from the main study.

\subsubsection{Data Collection Instruments}

The questionnaire is the heart of a survey operation (Kothari and Garg, 2014). Semi-structured questionnaires were used to collect data from the AHoDs. The questionnaires were divided into three parts as follows: Part A collected such data on the demographic profiles of respondents and departments. Part B collected data on recruitment practices while part F collected data on lecturers' performance.

\subsubsection{Reliability and Validity Tests}

Cronbach's alpha coefficient analysis (with the aid of Statistical Package for Social Sciences (SPSS) software) was used to examine the internal consistency of the measures as it is the most reliable test of inter-item consistency reliability for Likert scaled or rating scaled measures (Whitley, 2002 \& Robinson, 2009). The instrument had adequate reliability for the study with all the items hanging out well with others in all the sub-scales. They were all within the acceptable range of 0.70 to 0.9 as recommended by Tavakol and Dennick (2011) and George and Mallery (2003). Generally, the instrument was of an acceptable reliability standard with an overall scale reliability of 0.796 and a standard deviation of 0.06 . Content validity was ascertained by literature search to ensure that the items in the questionnaire were within the domain of the study concepts (Kimberlin \& Winterstein, 2008; Drost, 2011) and corroborated by a panel of experts (Cooper and Schindler, 2008; Drost, 2011; Aila \& Ombok, 2015). Construct validity, on the other hand, was conducted using Pearson Product Moment Correlations with the aid of SPSS version 21.0. Based on the significant values obtained by the significance (2-tailed) $<.05$, it was evident that all items in each sub-scale significantly correlated with their sub-scale totals, except for item 4 in the forecasting future requirements and action planning sub-scale. The item was excluded from the final analysis of the data. Generally, the questionnaire items were of adequate validity since they significantly correlated with their total subscales.

\subsubsection{Data Analysis}

The collected data were processed and organized for statistical analysis. Both descriptive and inferential statistics were used. Pearson's product moment correlation was used to determine the magnitude and direction of relationship between variables (Cooper and Schindler, 2008) while multiple regression used to predict the influence of recruitment practice on lecturers' performance. All tests of significance were computed at $\alpha=0.05$. The Statistical Package for Social Sciences (SPSS) version 21.0 aided data analysis.

\subsubsection{Model Specification}

The study sought to establish the influence of recruitment practice on lecturers' performance in Kenyan public universities. This objective was investigated by testing the null hypothesis that: recruitment practice has no influence on lecturers' performance in Kenyan public universities. Recruitment practice was measured using subscales, namely: examination of vacancy; locating, making contact and attracting candidates. The data for each of the two sub-scales was collected using a 5-point Likert scaled questionnaire. The Likert scale responses were then converted in continuous scale data by computing the mean response in each item. The multiple regression model in Equation 1 that follows was used to explore the hypothetical influence of the two aspects of recruitment practice on lecturers' performance in Kenyan public universities. The model was adapted from Cooper and Schindler (2008). 
$L P=a+\beta_{1 i} X_{1 i}+\varepsilon(1)$ Equation 1

Where:

LP

$\mathrm{X}_{\mathrm{i}(\mathrm{i}=1,2,)}$

$\mathrm{X}_{1}$

$\mathrm{X}_{2}$

$\varepsilon$

$\beta_{1 \mathrm{i}}$
$=$ Lecturers' Performance

$=$ Recruitment practice in which:

$=$ Examination of Vacancy

$=$ Locating, Making Contact and Attracting Candidates

$=$ Error term

$=$ Regression co-efficient

\section{Assumptions of Regression Analysis}

Most statistical tests rely upon certain assumptions about the variables used in the analysis (Osborne and Waters, 2002). Consequently, diagnostic tests were conducted on the collected data to confirm their suitability of for multiple regression analysis (Field, 2013). Normality was tested using Shapiro-Wilk's test (Thode, 2002; Gravetter \& Wallnau, 2000; Oso and Onen, 2013; Zar, 1999). Durbin Watson test was done to examine independence of errors at a range of $1.50-2.50$ (Tabachnick and Fidell, 2001; Keppel and Zedeck, 1989). The assumption of Multicollinearity was investigated using Tolerance and Variance Inflationary Factor (VIF) (O'Brien and Robert, 2007). Homoscedasticity and heteroscedasticity was examined using scatter plot. Independence of errors was examined using Durbin-Watson (Kothari and Garg, 2014; Fox, 1991). Appropriate action was taken in cases of violations of the assumptions.

\section{Results}

\subsection{Descriptive Statistics on Lecturers'Performance}

Lecturers' performance was summarized in four sub-scales, namely: quality of teaching and learning, research and publication, administration and responsibilities, and community engagement and other contributions. Table 2 indicates the summary of lecturer's performance ratings using means and standard deviation.

Table 2: Summary of Sub-Scales of Lecturers Performance

\begin{tabular}{lll}
\hline Sub-Scales in Lecturers Performance & Mean & SD \\
\hline Quality of Teaching and Learning & 4.27 & 0.53 \\
Research and Publication & 3.82 & 0.65 \\
Administration and Responsibilities & 4.22 & 0.54 \\
Community Engagement and Other Contributions & 3.75 & 0.76 \\
\hline Overall Mean Rating & $\mathbf{4 . 0 1}$ & $\mathbf{0 . 6 2}$
\end{tabular}

Source: Survey data (2020)

Table 2 demonstrates that the overall lecturer's performance in Kenyan public universities was above average. In a scale of 1 to 5 , the study established an overall mean $M=4.01(S D=0.62)$ indicating a fairly strong level of performance among the lecturers. Quality of teaching, as a dimension of performance, had the highest mean $M=4.27(S D=0.53)$, implying that lecturers performed best in Teaching and Learning compared to other dimensions of performance. Next was Administration and Responsibilities mean at $M=4.22(S D=0.54)$. Research and Publication came third with a mean rating of $M=3.82(\mathrm{SD}=0.65)$ while Community Engagement and Other Contributions came last with mean rating of $M=3.75(S D=0.76)$ respectively. Considering the above average means in all the dimensions, Kenyan university lecturers generally performed well in discharging their duties. The findings support those of Kara, Tanui and Kalai (2020) who established that a majority of lecturers in Kenyan public universities had the desired professional quality and engaged in quality instructional practices.

\subsection{Descriptive Statistics on Recruitment Practice}

The two sub-scales of recruitment practice were summarized using means and standard deviations. The findings are presented in Table 3. 
Table 3: Summary of Recruitment Practice

\begin{tabular}{lll}
\hline Sub-scales & Mean & $\begin{array}{l}\text { Standard } \\
\text { Deviation }\end{array}$ \\
\hline Examination of Vacancy & 4.58 & 0.53 \\
Locating, Making Contact and Attracting Candidates & 3.47 & 1.03 \\
Overall Mean rating of Human Resource Planning Practice & 4.02 & 0.77 \\
\hline
\end{tabular}

Source: Survey data (2020)

From Table 3, it is evident that public universities in Kenya have above average rating in their recruitment practices. This was reflected by an overall mean rating of $M=4.02(S D=0.77)$ in a scale of 1 to 5 . This reflects the respondents' satisfaction with recruitment practice in their universities. Specifically, the dimension of Examination of Vacancy received the highest rating $(M=4.58, S D=0.53)$, suggesting that many of the universities do better in this aspect as compared to Locating, Making Contact and Attracting Candidates $(M=3.47 ; S D=1.03)$.

\subsection{Relationship between Recruitment Practice and Lecturers'Performance in Kenyan Public Universities}

The study sought to establish the relationship between recruitment practice and lecturers' performance. To this extent, Pearson product moment correlation analysis was used to find out the magnitude and direction of the relationships between the individual aspects of recruitment practice and lecturers' performance as well as that of the overall recruitment practice and lecturers' performance, as shown in Table 4.

Table 4 Correlations between Recruitment Practice and Lecturers' Performance

\begin{tabular}{llll}
\hline Indicator & $\mathbf{n}$ & $\boldsymbol{r}$ & $\boldsymbol{P}$ \\
\hline Examination Vacancy & 136 & .351 & .000 \\
Locating, Making contract and Attracting Candidates & 136 & .188 & .029 \\
\hline Overall Recruitment Practice & $\mathbf{1 3 6}$ & $\mathbf{. 3 2 4}$ & $\mathbf{. 0 0 0}$ \\
\hline
\end{tabular}

Source: Survey data (2020)

It is evident that all the aspects of recruitment practice are directly correlated to lecturers' performance. The findings indicate that the strongest relationship was between examination of vacancy and lecturers' performance, as was reflected by a significant positive correlation coefficient $r=.351(p=.000)$. Comparatively, Locating, Making contract and Attracting Candidates, recorded a relatively weaker positive correlation with lecturers' performance. It was significant at $(r=.188, p=.029)$.

Overall, the correlation between recruitment practice and lecturers' performance was established to be positive and significant $(r=.324, p=.000)$. This suggests a positive association between the two variables, such that when the overall recruitment practice is improved then there would be a corresponding positive improvement in lecturers' performance. It was, therefore, concluded that recruitment practices in Kenyan public universities is positively associated with lecturers' performance. The findings of the study are in conformity with those of Saifaislam, Osman and AlQudah (2014), Suntanto and Kurniawan (2016), Rahmany (2018) and Murage, Sang and Ngure (2018) who established a significant positive relationship between the two variables although their studies ignored such facets of recruitment practice as Examination of Vacancy; Locating, Making Contact and Attracting Candidates. The research data were further subjected to multiple regression analysis to establish the influence of Recruitment practice on Lecturers' Performances in Kenyan public universities as in Table 5.

\subsection{The Influence of Recruitment Practice on Lecturers'Performance in Kenyan Public Universities}

To investigate the influence of recruitment practices on lecturers' performance in Kenyan public universities, the null hypothesis that "Recruitment practice has no influence on lecturers' performance in Kenyan public universities" was tested. This was done using multiple regression analysis, with the investigated null hypothesis being $\mathrm{H}_{0}: \beta_{1}=\beta_{2}=0$ and the corresponding alternative hypothesis being $\mathrm{H}_{1}$ : at least one $\beta_{\mathrm{i} \neq 0} 0$. If the null hypothesis is true, then from $\mathrm{E}(\mathrm{Y})=\beta_{0}+\beta_{\mathrm{i}=1,2} \mathrm{X}_{\mathrm{i}=1,2}$ the population mean of $\mathrm{Y}$ is $\beta_{2}$ for every $\mathrm{X}$ value, which indicates that $\mathrm{X}$ (recruitment practice) has no influence on Y (lecturers' performance) in Kenyan public universities, and the alternative being that X (recruitment practice) influences $Y$ (lecturers' performance) in Kenyan public universities.

Mean response across a set of statements of Likert-type scale responses in the measure of recruitment practice was 
computed to create an approximately continuous variable, within an open interval of 1 to 5 as determined to be suitable for the use of parametric data by Johnson and Creech (1983) and Sullivan and Artino (2013). High scale rating was interpreted to imply a corresponding high implementation of recruitment practice that would influence lecturers' performance. The priori significance level was set at 0.05 , such that if the $p$-value was less than 0.05 , then the null hypothesis would be rejected and conclusion reached that recruitment practice has a statistically significant influence on lecturers' performance. If the $p$-value was greater than 0.05 , it would be concluded that a significant difference does not exist. Table 5 shows the results of the regression model.

Table 5 Regression Model on Recruitment Practice on Lecturers' Performance

\begin{tabular}{|c|c|c|c|c|c|c|c|}
\hline Variable & $\mathrm{B}$ & SE & Beta & $\mathrm{t}$ & Sig. & $95 \% \mathrm{CI}$ & $\begin{array}{l}\text { Part } \\
\text { Correlation }\end{array}$ \\
\hline (Constant) & .942 & .594 & & 1.587 & .115 & $(-.232,2.116)$ & \\
\hline $\begin{array}{l}\text { Examination of } \\
\text { Vacancy }\end{array}$ & .484 & .128 & .325 & 3.795 & .000 & $(.232,0.737)$ & .307 \\
\hline $\begin{array}{l}\text { Locating, } \\
\text { Making Contact } \\
\text { and Attracting } \\
\text { Candidates }\end{array}$ & .106 & .111 & .082 & .959 & .339 & $(-.113,0.326)$ & .078 \\
\hline
\end{tabular}

$R=.360 ;$ Adjusted $R$ Square $=.116(S E=.58036) ; F=9.890, p=.000, \mathrm{df}\left(\mathrm{df}_{1}=2, \mathrm{df}_{2}=133\right)$

The model summary shows that recruitment practice, as measured by Examination of Vacancy, and Locating, Making Contact and Attracting candidates, accounts for $11.6 \%$ (Adjusted $R^{2}=.116$ ) of the variation in the lecturers' performance in Kenyan public universities. This implies that $11.6 \%$ of the variability in performance among lecturers in public universities in Kenya is explained by the combined changes of the two dimensions of recruitment practice: Examination of Vacancy, and Locating, Making Contact and Attracting Candidates. However, the two dimensions had a fairly weak joint correlation $(R=.360)$ with lecturer's performance. On the other hand, the ANOVA output results confirm that the level of recruitment practice is really a significant predictor of performance among lecturers in Kenyan public universities, $F(2,133)=9.890, p=.000$. The low value of $F$ suggests that the variability within each of the dimensions of recruitment practice and lecturers performance was generally smaller than variation between the variables. This indicates that the level of recruitment practice in Kenyan public universities can significantly predict lecturers' performance.

It is also evident that the two dimensions of recruitment practice reflected different levels of influence on lecturer's performance. On the one hand, Examination of Vacancy had a significant p-value $(t=3.795 ; p=.000)$ unstandardized coefficient value of 0.484 within a $95 \%$ C.I $(.232, .737)$. On the other hand, the coefficients value for Locating, Making Contact and Attracting Candidates was not significant $(B=-0.106 ; t=.959, p=.339)$. Nonetheless, given that one of the two dimensions had significant un-standardized co-efficient value, there is sufficient evidence to reject the null hypothesis $\left(\mathrm{H}_{0}: \beta_{l}=\beta_{2}=0\right)$ because at least one $\beta \mathrm{i} \neq 0$. Hence, the alternative hypothesis was supported and it was concluded that recruitment practices has statistically significant influence on lecturers' performance in Kenyan public universities.

A scrutiny of the standardized coefficient values confirms that the dimension of Examination of Vacancy had a relatively higher influence on lecturers' performance than Locating, Making Contact and Attracting Candidates. An improvement in Examination of Vacancy, as a dimension of recruitment practice, by one standard deviation would result in an improvement in lecturers' performance by .325 standard deviations. On the other hand, one standard deviation improvement in Locating, Making Contact and Attracting Candidates results in an improvement in lecturers' performance by only .082 standard deviations.

In addition, the study explored part correlation coefficients, which indicate the contribution of each of the aspects of Recruitment Practice to the total $R$ squared. The results show that the dimension of Examination of Vacancy has a partial correlation coefficient $r=307$, while the dimension of Locating, Making Contract and Attracting Candidates has a partial correlation $r=.078$. This demonstrates that Examination of Vacancy has a larger contribution to the model because it uniquely explains $9.4 \%$ of the variance in lecturers' performance. However, the dimension of Locating, Making Contract and Attracting Candidates uniquely explains less than $1 \%$ of the variance in lecturers' performance. It is noteworthy that squared part correlation values summed up was lower than 
total $R$ squared value for the model (11.6 per cent explained variance) because overlaps or shared variance were removed. Nonetheless, it was concluded that the recruitment practice regression model was adequate to predict lecturers' performance among public universities in Kenya. The model was statistically significant $F(2$, $133)=9.890, p=.000$, accounting for $11.6 \%$ (Adjusted $\left.R^{2}=.116\right)$ of the variation in lecturers' performance in Kenyan public universities.

The findings of the study affirm many theoretical arguments, for instance the decision-making theory (Simon, 1945; Mintzberg, 1973; Iyayi, 2002) which is the overarching theory, as well as the findings of other previous studies. Decisions are made in the areas of recruitment with specific reference to strategies to be adopted in recruitment and retention of employees for performance (Gberevie, 2010). Decision-making theory is premised on the fact that decision-making is at the very heart of business success in any organization (Gberevie, 2006). Decision-making theorists hold that decisions are the selection of a proposed course of action (Butler, 1992; Iyayi, 2002). With regards to the influence of recruitment on lecturers' performance, it can be argued that prudent decisions on the construction of valid job descriptions and specifications; identification of the most appropriate sources of candidates; identification of the best media to publicize vacancies; determination of the deliberate strategies that would yield the best candidates among others would lead to the attraction of sufficient and competent pool of applicants from which the best fit can be obtained, thus optimum performance.

Several empirical studies reiterate the influence of recruitment practice on employees' performance. In Afghanistan Civil Service, Rahmany (2018) established that recruitment process, among other variables, accounted for $95 \%$ variability in employees' performance. Much as the study ignored recruitment facets such as: examining vacancy, and locating, making contact and attracting candidates (Graham and Bennett, 1998) that the current study addressed. The variation it is greater the $11.6 \%$ (Adjusted $R^{2}=.116$ ) of the variation in lecturers' performance in Kenyan public universities as is in the current study. This could be because of the former examining the influence of recruitment alongside other variables.

In Kenya, via linear regression, Murage, Sang and Ngure (2018) found that recruitment and selection accounted for $14.6 \%$ of employees' performance in public universities in Nyeri County. The focus was, however, on ethical issues in recruitment and selection as opposed to the facets of recruitment such as: examining vacancy, and locating, making contact and attracting candidates which characterize the current study (Graham and Bennett, 1998). Moreover, the unit of analysis was non-teaching staff and not academic staff as in the current study. This would probably create disparities owing to different measures of performance used to gauge the two categories of university employees. Furthermore, the contribution of recruitment and selection were not established in isolation.

Examining the influence of recruitment and selection on the performance of employees in research institutions in Kenya, Ombui, Mukulu and Waititu (2014) established that recruitment and explained 37.4 of variation in employees' performance. The unique contributions of recruitment and selection were not established. Furthermore, the descriptors of recruitment were not revealed. The other studies that demonstrated a positive influence of recruitment on employee performance are Mokaya, Mukhweso and Njuguna (2013) and Suntanto and Kurniawan (2016). According to the latter, Recruitment accounted for $53.11 \%$ variation in performance in Batik Industry in Solo City, Indonesia. However, just like the other studies, they ignored the facets of recruitment such as: examining vacancy, and locating, making contact and attracting candidates which characterize the current study (Graham and Bennett, 1998).

On the flip side, examining the effect of recruitment, selection and placement on employee performance at PT Green Glovers in Indonesia, Suwarto and Subyantoro (2019) established that recruitment had no effect on employee performance. However, the study relied on a saturated sample of only 90 respondents in a one company which may not be suitable for generalization.

\section{Conclusion}

This study was aimed at establishing the influence of recruitment practice on lecturers' performance in Kenyan public universities. In conformity with the results of many previous studies, correlation results have revealed a statistically significant positive correlation with lecturers' performance. Similarly, regression analysis has revealed that that enhancement of recruitment practice can improve lecturers' performance. Consequently, it is recommended that public universities invest in recruitment practice, owing to its benefits. 


\section{References}

Abba, H.D., \& Mugizi, W. (2018). Performance of academic staff in polytechnics: An analysis of performance levels in North West Geo-political zone of Nigeria. Arts and Humanities Open Access Journal, 2(3), 198-203. Doi: 10.15406/ahoaj.2018.02.00056

Adeyemi, S. B. (2017). Lecturers' variables as predictors of academic performance in universities. Journal of Social Scienec, 50(1-3), 14-26

Afolabi, O. \& Idowu, H. (2019). African-Universities-Quality-management-Challenges-and-HigherEducation-Agenda. 10.4018/978-1-5225-9829-9.ch013.

Aguinis, H. (2009). Performance management. London: Pearson Prentice Hall.

Aila, F., \& Ombok, B. (2015). Validating measures in business research:Practical implications. International Journal of Science and Engineering, 1(9), 11-19.

Ajao, W. (2001). Cadbury is determined to move education forward. Vanguard, December 27, 2001, P. 16.

Ajayi, J.F.A. (1996). The African experience with higher education. The Association of African Universities, Accra.

Alemu, S. K. (2018). The meaning, idea and history of university/ higher education in Africa: A brief literature review. Forum for International Research in Education,(4) 3, 210-227

Analoui, F. (2007). Strategic human resource management. London: Thomson Learning.

Armstrong, M. (2009). Armstrong's hand book of human resource management practice. (11 ${ }^{\text {th }}$ ed.). London:

Kogan Page Ltd.

Armstrong, M. (2006). A Handbook of human resource management practice (10 ${ }^{\text {th }} e$.). London: Kogan Page.

Arnold, I. J. M (2008). Course level and the relationship between research productivity and teaching effectiveness. Journal of Economic Education, 39(4), 307-21.

Arreola, R. A. (2000). Developing a comprehensive faculty evaluation system. Bolton, M.A: Anker Publishing Company, Inc.

Ayiro, L. P. (2015, October, 3). The trouble with our varsities and how to sort them. Saturday Nation, Kenya, P.10-11.

Balam, E., \& Shannon, D. (2010). Student ratings of college teaching: A comparison of faculty and their students. Assessment and Evaluation in Higher Education, 35(2), 209-221.

Ball, S. J. (2012). The reluctant state and the beginning of the end of state education, Journal of Educational Administration and History, 44(2), 89-103. https://doi.org/10.1080/00220620.2012.658764

Barney, J.B. (1991). Firm resources and sustained competitive advantage. Journal of Management, 17(1), 99120.

Barney, J.B. (2001). Resource-based theories of competitive advantage: A ten year retrospective on the resource-based view. Journal of Management, 27, 643-650. doi:10.1177/014920630102700602

Bartlett, J. E., Kotrlik, J. W., \& Higgins, C. C. (2001). Organisational research: Determining appropriate sample size in survey research. Information Technology, Learning, and Performance Journal, 19(1), $1-8$.

Beardwell, J., \& Claydon, T. (2007). Human resource management: A contemporary approach (5 ${ }^{\text {th }}$ ed.). England: Pearson Education Ltd.

Bedggood, R., \& Donovan, J. (2012). University performance evaluations: What are we really measuring? Studies in Higher Education, 37(7), 825-842.

Boxall, P. (1996). The strategic human resource management debate and the resource- based view of the firm. Human Resource Management Journal, 6 (3), 59 - 75.

Boxall, P. (1998). Achieving competitive advantage through human resource strategy: Towards a theory of industry dynamics. Human Resource Management Review, 8(3), 236-288.

British Council (2014). Can higher education solve Africa's job crisis? Understanding graduate employability

in in Sub-Saharan Africa. Retrrievd
https://www.britishcouncil.org/sites/default/files/graduate employability in ssa final-web.pdf 
Brumbach, G. B. (1998). Some ideas, issues and predictions about performance management. Public Personnel Management, Winter: 387 -402.

Butler, R. (1992). Designing organizations: A decision making perspective. London: Routledge.

Cadez, S., Dimovski, V. \& Groff, M. Z. (2017). Research, teaching and performance evaluation in academia: The Salient quality. Studies in Higher education,42(8), 1455-1473. Doi: 10.1080/03075079.2015.1104659.

Commission for University Education (2014a). State of University Education in Kenya. (1 $1^{\text {st }}$ d.). Nairobi: $\quad$ CUE

Commission for University Education (2014b). Harmonized criteria and guidelines for appointment and promotion of academic staff in Universities in Kenya. Nairobi: CUE

Commission for University Education (2016). Universities standards and guidelines, 2014. Nairobi:

CUE

Cooke, F. L. (2000). Human resource strategy to improve organizational performance: A route for British firms? ESRC Future Work Programme, Working Paper NO. 9. Manchester School of Management, UMIST.

Cooke, F. L. (2001). Human resource strategy to improve organizational performance: A route for firms in Britain? International Journal of Management, 3(4), 321-339.

Cooper, D., \& Schindler, P. (2008). Business research methods (10 ${ }^{\text {th }} e d$.). Singapore: McGraw-Hill/Irwin.

Creswell, J. W. (2009). Research design: Qualitatitive, quantitative and mixed methods approaches $\left(3^{\text {rd }}\right.$ ed.). London: Sage Publications Inc.

DeCenzo, D. A, \& Robbins, P.R. (1998). Personnel/ human resource management (3 ${ }^{\text {rd }}$ ed.). $\quad$ New $\quad$ Delhi: Prentice - Hall of India.

Deepa S I, Manisha S, 2014. An exploratory study of student perception of instructor traits in effective learning. $\quad$ Universal Journal of Management, $2(1), 1-8$.

Denisi, S.A., \& Griffin, R. W. (2009). Human resource management (2 ${ }^{\text {nd }}$ ed.). New Delhi; Biztanra.

Dessler, G. (2008). Human resource management ( $9^{\text {th }}$ ed.). New Delhi: Prentice-Hall of India.

Drost, E. A. (2011). Validity and reliability in social science research. Education Research and perspectives, $38(1), 105-124$

Dugguh, S.I. \& Ayaga, D (2014). Job satisfaction theories: Traceability to employee performance in organizations. IOSR Journal of Business and Management, 16 (5), 11-18.

Ekwaoba, J. O., Ikeije, U. U., \& Ufoma, N. (2015). The impact of recruitment and selection criteria on organizational performance. Global Journal of Human Resource Management, 3(2), 22-33.

Essaw, D. W., \& Issahaku, J. (2019). The effectiveness of human resource management policies on teachers: A Case of Ghana education service in Tamale Metropolis, Ghana. Educational Research, 4(2), 153-162.

Field, A. (2013) Discovering statistics using IBM SPSS Statistics: and sex and drugs and rock ' $n$ ' roll ( $4^{\text {th }}$ ed.). London: Sage

Fox, J. (1991). Regression diagnostics. Washington DC: Sage Publications, Inc.

Ganyaupfu, E. M. (2013). Factors influencing academic achievement in quantitative courses among business students of Private Higher Education Institutions. Journal of Education and Practice, 4(15), $57-65$.

Gberebvie, D.E. (2006). Recruitment and quality academic selection: The case study of Covenant University. Ife Psychologia, 14 (2), 177-141.

Gberevie, E.S. (2010). Startegies for employee recruitment, retention and performance: Dimensionsof Federal Civil Service of Nigeria. African Journal of Business Management, 4(8), 1447-1456.

George, D. \& Mallery, P. (2003). SPSS for Windows step by step: A simple guide and reference. 11.0 update( $4^{\text {th }}$ ed.). Boston: Allyn \& Bacon.

Gill, J., \& Johnson, P. (1997). Research methods for managers. London: Paul Chapman Publishing.

Graham, H.T., \& Bennett, R. (1998). Human resources management $\left(9^{\text {th }}\right.$ ed.). Great Britain: $\quad$ Pearson Education Ltd. 
Gravetter, F. J., \& Wallnau, L.B. (2000). Statistics for the behavioral sciences ( $5^{\text {th }}$ d.). Belmont: Wadsworth Thomson Learning.

Gudo, C.O., Oanda, I.O, \& Olel, M.A, (2011). Role of institutional managers in quality assurance: Reflections on Kenya's university education, Australian Journal of Business Management Research, 1(2), 113- 124.

Herzberg, F., Mauster, B., \& Snyderman, B. (1959). The motivation to work. New York, Wiley

Hill, L., Lomas, L., \& MacGregor, J. (2003). Students' perceptions of quality in higher education. Quality Assurance in Education, 11 (1), 15-20.

Hossain, M. F., \& Rahman, S. (2019). Human resource management practice in he=igher education institutions in Bangladesh. IJARIIE, 5(6), 824-829

Hudson, R. (2016). Dominated by economics? Evidence of changing drivers of internationalization and its funding within higher education institutions in Europe. Higher Education Policy, 29(1), 1-19. https://doi.org/10.1057/hep.2015.4

Ikama, A. (2010). Benefits and challenges of workforce diversity: A case study of Consultancy Group on International Agricultural Research Centres (CGIAR) in Kenya. Unpublished MBA Thesis, University of Nairobi, Nairobi - Kenya

Ivancevich, J.M. (2010). Human resource management (11 ${ }^{\text {th }}$ ed.).New York: MCGraw- Hill/Irwin.

Iyayi, F. I. O. (2002). Decision-Making in underdeveloped organizations: An exploratory investigation. Nigeria Journal of Business Administration, 4(1), 1-22

Johnson, A. N., Kirimi, F. , \& Gathara, P. (2018). Implications of academic staff qualification on the quality of Bachelor of Education programmes in public universities in Kenya. International Journal of Innovative Research and Advanced Studies, 5(11), 119 - 127.

Johnson, D.R. \& Creech, J. C (1983). Ordinal measures in multiple indicator models: A simulation study of categorization error. American Sociological Review, 48(3), 398 - 407. Doi.org/10.2307/2095231.

Jones, J. J., \& Walters, D. L. (1994). Human resource management in education: Lncaster, Pa: Technomic Pub, Co.

Kaburu, J.K. (2014). An evaluation of quality of university education in Kenya during this massification era. Mediteterranean Journal of Social Sciences, 5(5), 345- 349

Kagondu, R., \& Marwa, S. M. (2017). Quality Issues in Kenya’s higher education institutions.

$J H E A / R E S A$ (15)1, 23-42

Kara, M. A., Tanui, E \& Kalai, J.M. (2020). Lecturer quality in public universities in Kenya. European Journal of Education Studies, 7(10), 302-324. Doi: 10.46827/ejes.v7i10.3306

Katua, N. T., Mukulu, E., \& Gachunga, G.H. (2014). Effect of employee resourcing strategies on the performance of commercial banks in Kenya. International Journal of education and Research, 2(1), $1-20$.

Keppel, G., \& Zedeck, S. (1989). Data analysis for research designs: Analysis of variance and multiple regression/correlation approaches. NY: W H Freeman/Times Books/ Henry Holt \& Co.

Kimathi, K. J., \& Embeywa, E. H. (2014). An evaluation of quality of university education in the massification era. Mediterranean Journal of Social Sciences, 5(5), 345-349.

Kimberlin, C. L., \& Winterstein, A.G. (2008). Validity and reliability of measurement instruments used in research. American Journal of Health System Pharmacists 65, 2276- 2284. Doi:10.2146/ajhp070364

Kothari, C.R., \& Garg, G. (2014). Research methodology: Methods and techniques, (2 ${ }^{\text {nd }}$ ed.). New Delhi: New Age International (P) Ltd. Publishers.

Kothari, C.R., (2004). Research methodology: Methods and techniques, (3 ${ }^{\text {nd }}$ ed.). New Delhi: New Age International (P) Ltd. Publishers.

Layman, L., Williams, L., \& Slaten, K. (2007). Note self: Make assignment meaningful. Computer Science Education. North Carolina State University: Raleigh, N.C, USA.

Liu, O. (2012). Student evaluation of instruction: in the new paradigm of distance education. Research in Higher Education, 27(3), 309 - 327. 
Malee-Bassett, R. (2015). Equity remains a most-important challenge facing global higher education. International Higher Education, (80), 5-6. https://doi.org/10.6017/ihe.2015.80.6131

Martin, M., \& Anthony, S (2007). External quality assurance in higher education: Making choices. Fundamentals of Education. Plan No. 85, Paris:II-UNESCO

Materu, P. (2007). Higher Education Quality Assurance in Sub-Saharan Africa: Status, Challenges, Opportunities and Promising Practices. World Bank Working Paper, No. 24. Washington, DC: African Region Human Development Department, World Bank.

McCowan, T. (2018). Quality of higher education in Kenya: Addressing the conundrum. InternationalJournal of Education Development, 60, 128-137.

Mintzberg, H. (1973). The nature of managerial work. New York: Harper and Row.

Molefe, G. N. (2010). Performance measurement dimensions for lecturers at selected universities: An international perspective. SA Journal of Human Resource Management,8(1). Doi:10.402/sajhrm.v8i1.243.

Monette, D. R., Sullivan, T. J., \& Dejong, R. C. (2002). Applied social research: Tool for human services $\quad\left(5^{\text {th }}\right.$ ed.). California: Harcout College Publishers.

Mugenda, G.A. (2008). Social science research: Theory and principles, Nairobi: Applied Research and Training Services.

Mukhwana, E., Oure, S., Too, J. and Some, D. (2016). State of post graduate research training in Kenya. Nairobi: Commission for University Education.

Murage, S. N., Sang, A., \& Ngure, S. (2018). Ethical issues in recruitment, selection and employee performance in public universities in Nyeri County, Kenya. International Journal of Business aand Social Science. 9(2), $194-203$.

Mwiria, K. \& Nyukuri, M.S. (1994). The management of double intakes: A case of Kenyatta University. Paris. UNESCO: International Institute of Educational Planning.

Ngolovoi, M. (2006). Means testing of student loans in Kenya. Presented at the Comparative and International Higher Education Policy: Issues and Analysis Workshop: University at Albany.

Nzuve, S. N. M. (2010), Management of human resources - A Kenyan perspective (4 ${ }^{\text {th }}$ ed.). Nairobi: Basic Modern management Consultants and Publisher.

O'Brien, R. M. (2007). A caution regarding rules of thumb for variance inflation factors. Quality and Quantity, $\quad$ 41, 673 - 690. Doi: 10.1007/s11135-006-9018-6

Oanda, I. O., \& Jowi, J. (2012). University expansion and the challenges to social developments in Kenya: Dilemmas and pitfalls. Journal of Higher Education in Africa, 10 (1), 49-71.

Oaya, Z.C, Ogbu, J., \& Remilekun (2017). Impact of recruitment and Selection strategy on employees' performance: A study of three selected manufacturing companies in Nigeria. International Journal of Innovation and Economic Development 3(3), 32-42. doi:10.18775/ijied.1849-75517020.2015.33.2003.

Obwogi, J. (2019). Effect of human resource practices on the quality of teaching staff at universities in Kenya. International Journal of Social Sciences and Information Technology, V(VI), 74-89

Odhiambo, G. (2018). The role of KenyanUniversities national development. Forum for International Research in Education, 4(3), 191-209.

Ombui, K., Mukulu, E., \& Waititu, G. A. (2014). The influence of recruitment and selection on the performance of employees in reaearch institutes in Kenya. International Journal of Science and Research, $3 I$ (5), 132-138.

Omona, J. (2013). Sampling in qualitative research: Improving the quality of research outcomes in Higher Education. Makerere Journal of Higher Education, 4 (2), 169-185.

Onwuegbuzie, A. J., \& Collins, K. M. (2007). A Typology of Mixed Methods Sampling Designs in Social Science Research. The Qualitative Report, 12(2), 281-316. https://doi.org/10.46743/2160-3715/ 2007.1638

Orodho, J.A. (2005). Elements of education and social science research methods. Nairobi: Masola Publishers 
Osborne, J.W., \& Waters, E. (2002). Four assumptions of multiple regression that researchers should always test. Practical Assessment, Research and Evaluation, 8(2), 1-5.

Oso,W.Y., \& Onen, D.(2013). A guide to writing research thesis and report .Nairobi: Satima Printers

Ponge, A. (2013). Graduate unemployment and un-employability in Kenya: Transforming university education to cope with market demands and the lessons for Africa. International Journal of Social Science Tomorrow, 2(3), 1-12.

Republic of Kenya (2007). Kenya Vision 2030: the popular version. Nairobi: Government Printer

Republic of Kenya (2012). The Universities Act No. 42 of 2012. Nairobi: Government Printer

Robinson, J. (2009). Triandis theory of interpersonal behaviour in understanding software privace behaviour in the South African context. Unpublished Masters Degree Thesis, University of the Witwatersrand.

Rubin, A. \& Babbie, E. (2001). Research methods for social work. Australia: Wadsworth.

Saifalislam, K.M., Osman, A., \& AlQudah, M. K. (2014). Human resource management practices: Influence of recruitment and selection, and training and development on the organizational performance of the Jordanian Public University. IOSR Journal of Business and Management, $16(5), 43-46$.

Shulman, L. (1992).. Ways of seeing, Ways of knowing, Ways of teaching, Ways of learning about teaching. Journal of Curriculum Studies, 28, 393-396.

Simon, H.A. (1945). Administrative behaviour (2 $2^{\text {nd }}$ Ed.). New York: Free Press.

Sinclair, H., \& Johnson, W. (2000). Students and staff perception of "good" teaching feedback. Educational Studies, 25(3), 1-5.

Sullivan, G., \& Artino, A. (2013). Analyzing and interpreting data from likert-type scales. Journal of Graduate Medical Education, 5 (4), 541-542. doi.org/10.4300/JGME-5-4-18

Sutanto, E.M. \& Kurniawan, M. (2016). Impact of recruitment, employee retention and labour relations on employee performance in Batik Industry in Solo City, Indonesia. International Journal of

Business and Society 17(2), 375-390.

Suwarto, F.X., \& Subyantoro, A. (2019). The effect of recruitment, selection and placement on employee performance. International Journal of Computer Networks and Communications Security 7(7), $126-134$.

Suwarto, F.X., \& Subyantoro, A. (2019). The effect of recruitment, selection and placement on employee performance. International Journal of Computer Networks and Communications Security 7(7), $126-134$.

Tabachnick, G. G., \& Fidell, L. S. (2001). Using multivariate statistics. Boston: Harvard University Press.

Tavakol, M., \& Dennick, R. (2011). Making sense of Cronbach's alpha. International Journal of Medical Education, 2, 53-55. DOI: $10.5116 /$ ijme.4dfb.8dfd

Teir, R. A.S. \& Zhang, R. (2016). The current practices of human resource management in higher educational institutions in Palestine. Journal of human and Labour Studies, 4(1), 65-83. Doi: 10.15450/jhrmls.v4n1a3

Teixeira, A. (2002). On the link between human capital and firm performance: A theoretical and empirical survey. FEP Working Paper No. 121, November p. 1414-156

Terence, H (1976). Adam Smith and the wealth of nations. The Journal of Law and Economics, 19(3), $507-528$

Thode, H. J. (2002). Testing for normality. New York: Mariel Dekker.

Torrington, D., Hall, L., \& Taylor, S. (2008). Human resource management. England: Pearson Educational Ltd.

Umar, M. (2018). Research fundamentals: Study design, population, and sample size. URNCST Journal,

$2(1), 1-7$

Wangenge-Ouma, G. (2008).Higher education marketisation and its discontents: the case of quality in 
Kenya. Higher Education, 56: 457. doi:10.1007/s10734-007-9104-2

Wanzala, O. (2015, October, 3). Suspension of courses puts regulator on the spot. Saturday Nation, Kenya, P.11.

Wanzala, W. (2013) Quest for quality and relevant higher education, training and learning in $\quad$ Kenya: An overview. Educational Journal, 2(2), 36-49.

White, A. (2008, 15, April). Managing academic performance: Understanding development in the academic environment. Guardian News and Media Limited, 1-29.

Whitley, B. E. (2002). Principals of research and behavioural science. Boston: McGraw-Hill

World Bank (2010). Financing higher education in Africa. Washington DC: The World Bank.

World Bank (2017). Higher Education for development: An evaluation of the World Bank group's support. Washington, DC: World Bank.

Yego H.C. (2016). Challenges facing higher education management of privately sponsored students programmes in Kenya. British Journal of Education 4(8), 52-62.

Zar, J.H. (1999).Bioistatistical analysis (4 ${ }^{\text {th }}$ Ed.).Upper Saddle River, NJ: Prentice Hall

\section{Acknowledgement}

The authors acknowledge the management of Rongo University, Kenya for the research grant they awarded in favour of this study. 